\title{
内リンパ霬局所免疫反応による前庭機能異常
}

\section{——外リンパ抗体価と自発眼振との関係 —}

\author{
富山 俊一・野中 学・八木 聰明 \\ Vestibular Disorder Following Immune Reaction \\ in the Endolymphatic Sac \\ - Relation of Spontaneous Nystagmus to \\ Perilymph Antibody Levels
}

Shun-ichi Tomiyama, Manabu Nonaka, Toshiaki Yagi

Department of Otolaryngology, Nippon Medical School

The relationship between an episode of spontaneous nystagmus and perilymph antibody levels following secondary immune reaction in the endolymphatic sac (ES) was examined in guinea pigs. Spontaneous nyztagmus was observed in 28 out of 46 animals. From day 2 to 7, the mean perilymph antiboody levels in the animals demonstrating spontaneous nystagmus were significantly higher than in animals without nystagmus. However, from day 14 to 28 , no significant difference was seen in the mean perilymph antibody levels between the animals with and without spontaneous nystagmus. These results suggest that immune reaction in the ES may actually induce vestibular disorders.

Key words: endolymphatic sac, immune reaction, spontaneous nystagmus, perilymph antibody

\section{はじめに}

近年, 内耳機能異常発生の原因の一つとして, 免疫組織障害を病因とする疾患が提唱され，ステ ロイド，免疫抑制鄅などによる烸床的治療効果 ${ }^{1}$ が報告されている。しかし一方, 免疫反応による 内耳障害の病態を解き明かす臨床材料証拠には之 しく，本疾患の本体の多くは未解決のままである。 そこで, 我々は内耳免疫障害の病態解明の一助之 して動物モデルを用いた基礎的研究を行ってきた。 その結果, モルモット内リンパ震局所の免疫反応

日本医科大学耳鼻咽喉科学教室
により，温度眼振反応の抑制 ${ }^{23)}$, 自発眼振の出 現 45)などの前庭機能異常が発生した。この結果 は免疫反応の強さに依存した前庭機能異常を示晙 した。実験に使用したハートレイ系モルモットは 雑采のため, 免疫反応の強さは均一ではない。今 回の研究は, 内耳免疫障害による前庭機能異常発 症への関与をさらに検討する目的で, 内耳免疫反 応の強さを示す外リンパの抗原特暴的抗体価と自 発眼振出現の有無との関係について検討した。

方法と材料

動物：ハートレイモルモット (雌) 350-400g 体 重 (埼玉実験動物)を用いた。 
表 1 外リンパ抗 KLH 抗体価と自発眼振出現との関係

\begin{tabular}{|c|c|c|c|}
\hline 生存期間 ${ }^{1)}$ & 実験匹数 & $\begin{array}{l}\text { 自発眼振非出現群 } \\
(\text { (抗) }\end{array}$ & $\begin{array}{l}\text { 自発眼振出現群 } \\
\text { (匹) 抗体価 }\end{array}$ \\
\hline 2 & 10 & (4) $4.5 \pm 1.4$ & (6) $15.4 \pm 9.2^{* * *}$ \\
\hline 4 & 10 & (5) $7.4 \pm 4.4$ & (5) $21.7 \pm 9.2^{* *}$ \\
\hline 7 & 9 & (3) $7.4 \pm 4.8$ & (6) $22.1 \pm 10.5^{*}$ \\
\hline 14 & 8 & (3) $7.6 \pm 1.5$ & (5) $11.9 \pm 7.6^{\mathrm{ns}}$ \\
\hline 28 & 8 & (3) $2.4 \pm 0.9$ & (6) $24.1 \pm 21.9^{\mathrm{n.s}}$ \\
\hline
\end{tabular}

1）日数，2）平均值 士標準偏差 $\times 10^{4}$ units $/ \mathrm{ml}$

$* * *=\mathrm{p}<0.01, * *=\mathrm{p}<0.02, *=\mathrm{p}<0.05, \mathrm{n} . \mathrm{s}=\mathrm{p}>0.05$

自発眼振非出現群 VS 自発眼振出現群 (Wilcoxon T)

抗原: Keyhole limpet hemocyanine (KLH) (Calbiochemist, CA) の associated form を使 用した。 KLH の希釈には燐酸緩衝生食水 $\mathrm{pH} 6.4$ を用いた。

内耳免疫動物の作製：詳細は既報したので簡略 に述べる6。 KLH による全身感作を行い，次いで KLH を内リンパ震（石）に注入刺激した。全身感

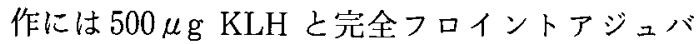
ントを混合し，皮下に注射し，2 週毎に $500 \mu \mathrm{g} \mathrm{K}$ LH と不完全フロイントアジュバントの混合の追 加免疫を行った。追加免疫の 2 週後, ネンブター ル, フェンタニール麻酔を行い, 手術用顕微鏡下 に, 後頭骨を開き, 硬膜内から右内リンパ震に直 接 $\mathrm{KLH}(100 \mu \mathrm{g} / 5 \mu \mathrm{l})$ を注入した。

自発眼振の観察：内リンパ震への KLH 抗原注 入後から 8 時間毎に自発眼振の出現を観察した。

外リンパ液採取と抗 KLH 抗体価の測定：詳細 は既報したので簡略に述べる”。外リンパ液の採 取は実験終了時に蝸牛基底回転鼓室階に小孔を開 き，ガラス毛細管を挿入し，血液を含まない外リ ンパ液を $3 \sim 5 \mu \mathrm{l}$ 採取した。抗体価の測定には $\mathrm{E}$ LISA 法を用いた。二次抗体には羊抗モルモット IgG Fc 抗体を用いた。既知の高力価のモルモッ 卜抗 KLH IgG抗体を有する血清を標準血清とし, 力価を Unit/ml にて表した。

実験計画：内リンパ震への KLH 抗原二次刺激 後から2，4，7，14，28日間生存の5 群を作成し, 各 生存期間での自発眼振の出現，持続時間を計測し， 実験終了時に外リンパ液を採取した。実験終了時 に中耳炎を認めた動物や，中耳腔骨異常発育によ り外リンパ採取不能であった動物を除外した46匹 で検討した。
推計学的検定 : 自発眼振の出現時期および持続 時間，外リンパ抗体価は各動物群の平均值と標準 偏差で表した。各群間の比較は Wilcoxon T (対 応なし）にて検定した。

\section{結果}

全観察期間で 46 匹中 28 匹麻猈性自発眼振の 出現を認めた。内 5 匹では刺激性眼振が先行した。

自発眼振が観察された 28 匹での平均出現時期 は $21.5 \pm 7.6$ 時間目であった。

自発眼振の平均持続時間は計測可能だった， 4 日間生存以上動物の 22 匹で $41.8 \pm 18.1$ 時間であ った。

生存期間別では，2 日間生存で 10 匹中 6 匹，4 日間生存で 10 匹中 5 匹，7 日間生存で 9 匹中 6 匹， 14日間生存で 8 匹中 5 匹，28日間生存で 9 匹中 6 匹に自発眼振を認めた。

実験終了時での外リンパ抗 KLH 抗体価を各生 存期間別に自発眼振を認めた動物 (眼振出現動物) と認めなかった動物（眼振非出現動物）とで比較 検討した結果を表 1 亿示す。眼振出現動物の外り ンパ抗 KLH 抗体価が眼振非出現動物と比較して 有意に上昇したのは，2 日目，4日目，7日目であ った（各々 $\mathrm{p}<0.001, \mathrm{p}<0.05, \mathrm{p}<0.05$, Wilcoxon T)。しかし，14日目，28日目採取時の外リンパ抗 $\mathrm{KLH}$ 抗体価では, 眼振出現動物と眼振非出現動 物とに有意な差がなかった。

\section{考 察}

本実験で観察された自発眼振が内リンパ囊への 非特異的刺激によるものではなく，内リンパ裹で の免疫反応に起因することをこれまでの研究で明 らかにしてきた (4)8)。今回の研究の結果，自発眼 振出現群の外リンパ抗 KLH 抗体価が自発眼振非 
出現群と比較して二次刺激後 2 日目, 4 日目, 7 日 目では有意に上昇していた。この結果は本実験系 における自発眼振の出現が免疫反応依存性の現象 であることをさらに明らかにした。

自発眼振出現の機序として, 膜迷路破裂による 外リンパ $\mathrm{K}^{+}$イオンの上昇 ${ }^{910)}$ や内耳压の急激な 変化 ${ }^{11)}$ が主因であると考えられている。

本実験系での自発眼振の出現機序には，化学作 動物質による前庭感覚組織への直接刺激と膜透過 性え進によるリンパ液電解質変化と急激な内耳厈 変化の 3 要素の関与が推測される。

本害験モデルでの内リンパ裹での組織学的変化 はIII型免疫反応を呈する。内リンパ囊への KLH 原二次感作後 3 4 時間目頃加ら多核球を主体と した急性炎症細胞の内リンパ衰への遊走浸潤が起 り，12時間後には最大に達し, 以後 3 日間は内リ ンパ裹腔と周囲組織に炎症細胞が充満する 発眼振の平均出現時期が今回の 8 時間毎の観察で 平均 21 時間目であり，その持続期間が平均 41 時 間であった。内リンパ囊二次抗原刺激後 1 時間毎 に観察した以前の結果では刺激性自発眼振が平均 14 時間目に，麻瘏性自発眼振は平均 23 時間目に 出現したら。従って，本実験モデルにおけるる自 発眼振の発生が内リンパ囊での急性炎症反応の発 生時期と殆ど一致していることから，自発眼振発 生機序として急性炎症時に放出遊離された化学作 動物質による前庭感覚組織への直接刺激，さらに は内リンパ膜透過性え進による電解質異常の発生 が推測される。

また，本実験モデルでは内リンパ水腫の急激な 成長が内リンパ裹二次抗原刺激後 12 時間目頃から

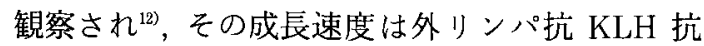
体佂依存性であった ${ }^{133}$ 。従って，本実験で外リン パ抗 $\mathrm{KLH}$ 抗体価が高值を示した動物には急激な 内耳圧変化の発生が推測される。

本実験で14日目以後に採取した外リンパ抗 KL $\mathrm{H}$ 抗体価でも，自発眼振出現動物に抗 KLH 抗体 価の高い傾向が見られたが，推計学的には有意で はなかった。この結果は, 自発眼振出現を決定し ている因子が免疫反応初期の免疫反応程度と密接 に関係していることを示唆した。以上のことから， 急性炎症反応で放出されるアナフィラトキシン, $\mathrm{PAF}$, 活性酸素, ライソゾーム物質なよ゙の化学作 動性因子による内耳組織障害の発生を示唆し, 今
後検討が必要である。

\section{まとめ}

今回の研究結果は, 内リンパ震局所での免疫反 応の程度と自発眼振出現との密接な関係を明示し, 臨床においても前庭機能異常病因として内耳免疫 障害による発生機序の存在を推察させるものであ った。

本研究の一部は厚生省特定疾患前庭機能異常調 查研究班および文部省一般研究 C の研究費による あのである。

\section{文献}

1) McCabe BF : Autoimmune sensorineral hearing loss. Ann Otol Rhinol Laryngol $88: 585-589,1979$

2）野中 学, 富山俊一, 八木聡明：モルモット 内リンパ震局所兔疫反応の温度眼振に及ぼす 影響. 日耳鼻 $93: 1973-1977,1990$

3）富山俊一, 野中 学, 八木聡明：内リンパ衰 局所二次免疫反応動物での盜度眼振経過とそ の組織学的検討. Otol Jpn 1:28-35，1991

4) 野中 学, 富山俊一：内リンパ囊局所免疫反 応モルモットの前庭機能障害について，日耳 鼻 $94: 1748-1755,1991$

5) Nonaka M, Tomiyama S, Gotoh Y : Vestibular disorders following immune response of the endolymphatic sac in the guinea pig. Ann Otol Rhinol Laryngol 101 Suppl $157: 54-57,1992$

6) Tomiyama S, Harris JP : Elevation of inner ear antibody levels following direct antigen challenge of the endolymphatic sac. Acta Otolaryngol 107 : 202-209, 1989

7) Tomiyama S, Harris JP : The endolymphatic sac: Its importance in inner ear immune response. Laryngoscope $96: 685$ 691, 1986

8) Tomiyama S, Nonaka M, Toshiaki $Y$, et al: Immunological approach to Meniere's disease : Vestibular immune injury following immune reaction of the endolymphatic sac. ORL J Otorhinolaryngol Relat Spec. (in print)

9) Lawrence M, McCabe BF : Inner ear mechanism and deafness; Special considera- 
tion of Meniere's syndrome. JAMA 171 : 1927-1932, 1959

10) Silverstein $H$ : The effects of perfusing the perilymphatic space with artificial endolymph. Ann Otol Rhinol Laryngol 79 : 754-765, 1970

11) Williams HL Jr: A review of the literature as to the physiologic dysfunction of Meniere's disease : a new hypothesis as to its fundamental cause. Laryngoscope $75: 1661-1689,1965$

12) Tomiyama $S$, Yagi $T$, Sakagami $M$, et al : Immunological pathogenesis of endo- lymphatic hydrops and its relation to Meniere's disease. Scanning Electron Microscopy International. in print.

13) Tomiyama $S:$ Endolymphatic hydrops induced by immune response of the endolymphatic sac : Relation to perilymph anibody levels. Ann Otol Rhinol Laryngol 101, Suppl 157:48-53, 1992

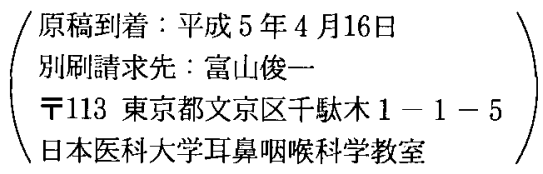

